\title{
Hydration for health hypothesis: a narrative review of supporting evidence
}

\author{
Erica T. Perrier ${ }^{1}$ - Lawrence E. Armstrong ${ }^{2,3}$. Jeanne H. Bottin ${ }^{1}$ - William F. Clark ${ }^{4}$ - Alberto Dolci ${ }^{1}$. \\ Isabelle Guelinckx ${ }^{1}$ - Alison Iroz ${ }^{1} \cdot$ Stavros A. Kavouras $^{5} \cdot$ Florian Lang $^{6} \cdot$ Harris R. Lieberman $^{7} \cdot$ Olle Melander $^{8}$. \\ Clementine Morin ${ }^{1} \cdot$ Isabelle Seksek $^{1} \cdot$ Jodi D. Stookey $^{9} \cdot$ Ivan Tack $^{10}$. Tiphaine Vanhaecke ${ }^{1} \cdot$ Mariacristina Vecchio $^{1}$. \\ François Péronnet ${ }^{11}$
}

Received: 24 February 2020 / Accepted: 28 May 2020 / Published online: 6 July 2020

(c) The Author(s) 2020

\begin{abstract}
Purpose An increasing body of evidence suggests that excreting a generous volume of diluted urine is associated with shortand long-term beneficial health effects, especially for kidney and metabolic function. However, water intake and hydration remain under-investigated and optimal hydration is poorly and inconsistently defined. This review tests the hypothesis that optimal chronic water intake positively impacts various aspects of health and proposes an evidence-based definition of optimal hydration.

Methods Search strategy included PubMed and Google Scholar using relevant keywords for each health outcome, complemented by manual search of article reference lists and the expertise of relevant practitioners for each area studied.

Results The available literature suggest the effects of increased water intake on health may be direct, due to increased urine flow or urine dilution, or indirect, mediated by a reduction in osmotically -stimulated vasopressin (AVP). Urine flow affects the formation of kidney stones and recurrence of urinary tract infection, while increased circulating AVP is implicated in metabolic disease, chronic kidney disease, and autosomal dominant polycystic kidney disease.

Conclusion In order to ensure optimal hydration, it is proposed that optimal total water intake should approach 2.5 to 3.5 $\mathrm{L} \mathrm{day}^{-1}$ to allow for the daily excretion of 2 to $3 \mathrm{~L}$ of dilute $\left(<500 \mathrm{mOsm} \mathrm{kg}^{-1}\right)$ urine. Simple urinary markers of hydration such as urine color or void frequency may be used to monitor and adjust intake.
\end{abstract}

Keywords Water $\cdot$ Renal $\cdot$ Metabolic $\cdot$ Arginine vasopressin $\cdot$ Copeptin

Erica T. Perrier

erica.perrier@danone.com

1 Health, Hydration \& Nutrition Science, Danone Research, Route Départementale 128, 91767 Palaiseau cedex, France

2 Department of Kinesiology, University of Connecticut, Storrs, CT, USA

3 Hydration \& Nutrition, LLC, Newport News, VA, USA

4 London Health Sciences Centre and Western University, London, ON, Canada

5 College of Health Solutions and Hydration Science Lab, Arizona State University, Phoenix, AZ, USA

6 Department of Physiology, Eberhard Karls University, Tübingen, Germany
7 Westwood, MA, USA

8 Department of Clinical Sciences Malmö, Lund University, Malmö, Sweden

9 Children's Hospital Oakland Research Institute, Oakland, CA, USA

10 Explorations Fonctionnelles Physiologiques, Hôpital Rangueil, Toulouse, France

11 École de Kinésiologie et des Sciences de l'activité Physique, Faculté de Médecine, Université de Montréal, Montréal, QC, Canada 


\section{Introduction}

Water is the largest constituent of the human body, representing roughly 40 to $62 \%$ of body mass [1]. Water balance is constantly challenged by transepidermal, respiratory, fecal and urinary losses, with mean daily water turnover of $3.6 \pm 1.2 \mathrm{~L} \mathrm{day}^{-1}$ [2] or 2.8 to 3.3 and 3.4 to $3.8 \mathrm{~L} \mathrm{day}^{-1}$ in women, and men, respectively [3]. Only a small amount of water is produced in the body (metabolic water, 0.25 to $0.35 \mathrm{~L} \mathrm{day}^{-1}[2,4]$ ) and the human body has a limited capacity to store water; so water losses must be replaced daily. Thus, water has been called the 'most essential' nutrient $[5,6]$.

The maintenance of body water balance is so critical for survival that the volume of the body water pool is robustly defended within a narrow range, even with large variability in daily water intake. Evidence for this effective defense is found in population studies [4], observations of habitual low- vs. high-volume drinkers [7, 8], and water intake interventions [8-10], all of which demonstrate that large differences or changes in daily water intake do not appreciably alter plasma osmolality, thereby substantiating the stability of total body water volume. This tight regulation is governed by sensitive osmotic sensing mechanisms which trigger two key response elements: (1) the release of arginine vasopressin (AVP), which acts via vasopressin V2 receptors (V2R) on the renal collecting ducts, initiating renal water saving when water intake is low; (2) the triggering of the sensation of thirst to stimulate drinking.

Despite its importance, water is also referred to as a forgotten [11, 12], neglected, and under-researched [13] nutrient. This is reflected by discrepancies between regional water intake recommendations [4, 14], and the fact that these reference values represent Adequate Intakes (AIs). The AIs are based upon observed or experimentally derived estimates of average water intake with insufficient scientific evidence to establish a consumption target associated with a health risk or benefit. In practice, from the perspective of the general public, water may not even be visible in dietary guidelines (e.g., www.choosemyplate.gov). The implicit message is that there is little or no need to pay attention to water intake except in extreme situations; thirst is implicitly assumed to be an adequate guide.

\section{Hypothesis}

This review advances the hypothesis that optimal water intake positively impacts various aspects of health. We propose an evidence-based definition of optimal hydration as a water intake sufficient to avoid excessive AVP secretion and to ensure a generous excretion of dilute urine, sufficient to avoid chronic or sustained renal water saving. For many, this would imply drinking somewhat beyond physiological thirst and likely more than the often-repeated target of 'eight glasses of water per day' called into question by Valtin [15] and others for lack of supporting evidence-based health outcomes. Here, we review the existing evidence for two specific mechanisms of action of how increased water intake may impact health: (1) the direct effect of increased urine flow on kidney and urinary tract health, and (2) the indirect effect of lowering AVP concentration on kidney and metabolic function. We conclude with a proposal for a range of water intake that provides optimal hydration.

\section{Literature review and search strategy}

Searches for relevant literature were divided by subtopic. Each subtopic was investigated by a group of two to three authors and involved at least one expert with current, relevant clinical practice or recent research activity. Search strategy included PubMed and Google Scholar using relevant keywords for each health outcome (e.g., for kidney stones: kidney, stones, lithiasis, fluid, water, urine, flow, volume). This was accompanied by manual search of article reference lists and the publication knowledge and expertise of relevant practitioners for each area studied (e.g., nephrology, physiology, metabolic health). For health outcomes included in Tables 1 and 2, only human studies (observational or interventional) were included; animal or mechanistic work is cited where relevant to describe or support a plausible mechanism. No systematic assessment of study quality was performed. The initial search included articles available through the end of 2018; however, subsequent modifications to the manuscript resulted in the inclusion of some more recent references.

\section{Direct effect of increased water intake to increase urine flow}

While total body water and plasma osmolality are defended within a narrow range, urine volume adjusts water losses to compensate for fluctuations in daily water intake and insensible losses. Urine output adjusts quickly to changes in water intake, and 24-h urine volume is a reasonable surrogate marker for high or low daily water intake in healthy adults in free-living conditions [16]. Here, we review the evidence for the importance of high urine flow in the secondary prevention of kidney stones and urinary tract infection. A detailed description of individual studies is provided in Table 1. 
Table 1 Studies reporting a relationship between fluid intake and/or urinary hydration biomarkers and health outcomes related to urine dilution: kidney stones and urinary tract infection

\begin{tabular}{|c|c|c|}
\hline \multirow{2}{*}{$\begin{array}{l}\text { Author (year) } \\
\text { Study type, cohort name, follow-up } \\
\text { period } \\
\text { Population }\end{array}$} & \multicolumn{2}{|c|}{$\begin{array}{l}\text { Fluid intake or urinary hydration marker associated with } \\
\text { health outcome }\end{array}$} \\
\hline & $\begin{array}{l}\text { Total fluid } \\
\text { intake volume } \\
(\text { TFI, L·day } \\
\text {-1) }\end{array}$ & $\begin{array}{l}\text { 24-h urine volume }\left(\mathrm{UVol}, \mathrm{L} \cdot \mathrm{day}^{-1}\right) \text { or } \\
\text { Urine osmolality }\left(\mathrm{UOsm}, \mathrm{mOsm} \cdot \mathrm{kg}^{-1} \text { ) }\right.\end{array}$ \\
\hline
\end{tabular}

Borghi et al. (1996) [23]

Case-control

Recurrent stone formers

vs. healthy controls

Borghi et al. (1996) [23]

RCT, 5-year follow-up

Recurrent stone formers

Curhan et al. (2004) [117]

Prospective, NHS II cohort, 8-year

follow-up

General population (women)

Curhan \& Taylor (2008) [24]

Pooled retrospective study of 3 cohorts

(NHS I, NHS II, HPFS)

General population
UVol, Mean [sd]

Stone formers: 1.04 [0.24]

Controls: 1.35 [0.53]

UVol, Mean [sd]

Intervention:

Pre: $1.1[0.2]$

Post: $2.6[0.4]$

Control:

Pre: 1.0 [0.2]

Post: $1.0[0.2]$

TFI, quintiles

Q1: $\leq 1.43$

Q2: $1.43-1.85$

Q3: $1.85-2.25$

Q4: 2.25-2.77

Q5: $\geq 2.77$

UVol, Cutoff value

From 1.5 to $\geq 2.5$

TFI, quintiles

Q1: $<1.28$

Q2: $1.28-1.67$

Q3: $1.67-2.05$

Q4: 2.05-2.54

Q5: $\geq 2.54$

Hooton et al. (2018) [42]

RCT, 12-month follow-up

Recurrent UTI (women)
TFI (intervention group), Mean [sd]

Pre: $1.1[0.1]$

Post: $2.8[0.2]$
UVol (intervention group), Mean [sd]

Pre: 0.9 [0.2]

Post: $2.2[0.3]$

UOsm (intervention group), Mean [sd]

Pre: 721 [169]

Post: 329 [117]
Risk: Stone formers had lower spontaneous $24 \mathrm{~h}$ urine volume than age, sex, body weight, and socioeconomicmatched controls

Benefit: Increasing urine volume reduced kidney stone recurrence ( $12 \%$ vs. $27 \%$ in control group), time between episodes, and urine supersaturation in stone formers

Benefit: Reduction in multivariate-adjusted $\mathrm{RR}$ for incident kidney stones in women in Q3, Q4, and Q5 (RR 0.79, 0.72, and 0.68 , respectively), compared to reference (women with $\mathrm{FI} \leq 1.43 \mathrm{~L} \cdot$ day $^{-1}$ )

Benefit: Across three cohorts including 2,237 stone formers, individuals with a urine volume ranging from $1.5 \mathrm{~L}$ to more than $2.5 \mathrm{~L} \cdot$ day $^{-1}$ were shown to be at lower risk of developing kidney stones with corresponding RR ranging from 0.46 (urine volume 1.5 to $1.74 \mathrm{~L} \cdot \mathrm{day}^{-1}$ ) to 0.22 (urine volume $\geq 2,5 \mathrm{~L} \cdot \mathrm{day}^{-1}$ ), compared to reference (urine volume $\leq 1.0 \mathrm{~L} \cdot$ day $^{-1}$ )

Benefit: Reduction in multivariate-adjusted RR for incident kidney stones in men in Q5 $(\mathrm{RR}=0.71)$, compared to reference (men with $\mathrm{FI}<1.28 \mathrm{~L} \cdot \mathrm{day}^{-1}$ )

Benefit: $48 \%$ reduction in UTI recurrence in intervention group vs. control; increased time between episodes; reduction in antibiotic use

Empty cells denote that this variable was not reported

HPFS Health Professionals Follow-Up Study; NHS I Nurses' Health Study; NHS II Nurses' Health Study II; RCT Randomized Controlled Trial; $R R$ Relative risk; $s d$ Standard Deviation; TFI Total Fluid Intake, volume of drinking water plus other beverages; UTI Urinary Tract Infection

\section{Kidney stones}

Kidney stones are hard crystalline mineral deposits that form inside the kidney or urinary tract. They occur in $10 \%$ of the population worldwide [17] and recurrence is high: 40 to $60 \%$ of stone formers will relapse within 5 years following a first episode [18-20]. Stone formation results from dietary, genetic and/or environmental factors. In particular, low fluid intake and low urine volume have been shown to be significant risk factors for kidney stones in first-time and recurrent stone formers (Table 1) [21-24]. Mechanistically, low urine volume leads to higher concentrations of urinary solutes and promotes urine supersaturation, favoring crystal nucleation and stone growth [25]. Conversely, increased water intake facilitates the flushing of crystals by increasing urine flow. 
In a 5-year randomized controlled trial (RCT), patients were either instructed to increase water intake to achieve a urine volume of $2 \mathrm{~L} \mathrm{day}^{-1}$ without any further dietary changes or were assigned to a control group receiving no intervention [23]. Over the follow-up period, the recurrence of stones was lower (12\%) in the intervention group, who maintained a urine volume of more than $2.5 \mathrm{~L}_{\text {day }}{ }^{-1}$, compared with the control group (27\% recurrence) whose urine volume remained at about $1.2 \mathrm{~L} \mathrm{day}^{-1}$. Two systematic reviews on this topic have concluded that high water intake reduces long-term risk of kidney stone recurrence [26, 27]. In agreement with these findings, the European Association of Urology and the American Urological Association current guidelines for the secondary prevention of kidney stones recommend stone-formers maintain a fluid intake that will achieve a urine volume of at least 2.0 to $2.5 \mathrm{~L}$ daily [28, 29]. Interestingly, increasing fluid intake also appears to be perceived as one of the easiest lifestyle changes to make with respect to stone recurrence. While dietary factors also influence stone formation, patients with recurrent kidney stones reported being more confident in their ability to increase fluid intake, compared to changing other dietary factors or taking medicine [30].

In terms of primary prevention, we are only aware of one study investigating the effects of increased habitual fluid intake [31]. In an area of Israel with a high incidence of urolithiasis, healthy inhabitants of one town participated in an education program that encouraged adequate fluid intake, while inhabitants of a second town did not participate in the program. At the end of the 3-year study period, urine output was found to be higher and incidence of urolithiasis lower in the intervention group compared with the control group. To date, no recommendation for primary stone prevention has been proposed. However, considering the aggregate of observational evidence, including a successful RCT for secondary prevention, as well as a clear mechanism of urine dilution to avoid supersaturation and stone formation, increased water intake among low drinkers in general would appear to be a reasonable, easy and cost-effective way to reduce urolithiasis recurrence in known stone formers [32] as well as in primary prevention [33].

\section{Urinary tract infection}

Urinary tract infections (UTI) are bacterial contaminations of the genitourinary tract affecting a large part of the female population and resulting in general discomfort and decreased quality of life. Increased water intake is sometimes recommended in clinical practice as a preventive strategy for UTI in women suffering recurrent events. However, the empirical evidence for any relationship between UTI and water intake or urinary markers of hydration is equivocal. Several non-randomized studies reported that low intake of fluids or reduced number of daily voids are associated with increased risk of UTI [34-38]. In contrast, other published data show no association between fluid intake and the risk of UTI, no difference in fluid intake between women with recurrent infections and healthy controls, and no effect of increased water intake on UTI risk [39, 40]. A small crossover trial published in 1995 demonstrated that self-assessment of urine concentration encouraged lower urine osmolality and reduced frequency of UTI [41]; however, the study had a number of methodological problems including large number of participants lost to follow-up, lack of a proper control group, and not reporting fluid intake.

Recently, Hooton et al. published the first RCT assessing the effect of increased water intake on the frequency of acute uncomplicated lower UTI in premenopausal women [42]. One hundred and forty women suffering from recurrent UTI with low fluid intake and low urine volume were randomly assigned to increase their daily water intake by $1.5 \mathrm{~L}$ or to maintain their usual intake for 12 months. Increasing water intake (to $2.8 \mathrm{~L} \mathrm{day}^{-1}$ ) and urine volume (to $2.2 \mathrm{~L} \mathrm{day}^{-1}$ ) resulted in a $48 \%$ reduction in UTI events. Of note, a second benefit to increasing water intake was a reduction of antibiotic use, for prophylaxis or treatment of UTI. The proposed mechanism for the improvement in UTI recurrence was that increasing void frequency and urine volume facilitated the flushing of bacteria and thus reduced bacterial concentration in the urinary tract. More recently, a second study of elderly patients in residential care homes found that encouraging increased fluid intake by implementing structured 'drink rounds' multiple times per day reduced UTIs requiring antibiotics by $58 \%$, and UTIs requiring hospital admission by $36 \%$ [43]. While the study did not measure individual increases in fluid intake during the intervention, the magnitude of reduction in UTI is substantial, and similar to that reported by Hooton et al. in a younger population, supporting the role for increased fluid intake in the secondary prevention of UTI.

\section{Take home points}

- Increasing fluid intake is effective in the secondary prevention of kidney stones and urinary tract infection. Little is known about whether high fluid intake is also effective in primary prevention.

- Mechanistically, increasing fluid intake results in lower urine concentration and increased urine flow. The former may be important in preventing supersaturation and crystal formation, while the latter encourages frequent flushing of the urinary tract which may be helpful for both kidney stone and UTI prevention.

- European and American urological associations encourage maintaining a fluid intake sufficient to produce 2 to $2.5 \mathrm{~L}$ of urine per day to reduce risk of stone formation. 


\section{Indirect effect of increased water intake: mechanisms mediated by reducing circulating AVP}

AVP is a critical hormone for the regulation of body fluid homeostasis. It can be secreted in response to small fluctuations of serum osmolality and primarily regulates fluid volume through its antidiuretic action on the kidney. Binding of AVP to the V2-receptors (V2R) located in the renal collecting ducts, induces translocation of aquaporin-2 to the cellular membrane and allowing increased water reabsorption [44] and the defense of total body water and plasma osmolality. Copeptin, a stable C-terminal fragment of the AVP precursor hormone released in a 1:1 ratio with AVP, is a surrogate marker for AVP secretion [45]. The recent availability of an ultra-sensitive assay for copeptin has dramatically increased research on AVP or copeptin and health outcomes. Lower circulating copeptin is associated with improved metabolic and renal outcomes (Table 2).

\section{AVP and metabolic dysfunction}

In addition to its well-defined role in concentrating urine and regulating body water via the V2R, AVP also acts on other AVP receptors ( $\mathrm{V} 1 \mathrm{aR}$ and $\mathrm{V} 1 \mathrm{bR}$ ) which occur in a variety of central and peripheral tissues, with multiple and wide-ranging physiological effects [46]. AVP may play an important role in the development of metabolic disease because it stimulates hepatic gluconeogenesis and glycogenolysis through $\mathrm{V} 1 \mathrm{aR}[47,48]$ and triggers release of both glucagon and insulin through V1bR in pancreatic islets [49]. Moreover, AVP stimulates the release of adrenocorticotrophic hormone (ACTH) via V1bR in the anterior pituitary gland, thereby leading to elevated adrenal cortisol secretion and prompting undesirable cortisol-mediated gluconeogenesis [50, 51].

High plasma copeptin levels have been associated with insulin resistance and metabolic syndrome in cross-sectional population and community-based studies $[52,53]$. Pooled data from three large European cohorts also show that participants in the top tertile of copeptin have higher fasting plasma glucose compared to the bottom and medium tertiles, and are more likely to have type 2 diabetes (T2DM) [54]. Moreover, copeptin has been consistently identified as an independent predictor of T2DM in four European cohorts (Table 2) [55-58], suggesting that AVP contributes to the development of the disease. Furthermore, within diabetic patients, individuals with the highest copeptin level had higher HbA1c levels [59], were more likely to develop metabolic complications, heart disease, death and all-cause mortality $[60,61]$.

A causal role for AVP in metabolic disorders is supported by preclinical evidence showing that high AVP concentration impairs glucose regulation in rats, an effect reversed by treatment with a selective $\mathrm{V} 1 \mathrm{aR}$ antagonist $[62,63]$. In humans, causality is also supported by recent evidence from a Mendelian randomization approach study which reported that certain single nucleotide polymorphisms within the AVP-neurophysin II gene were associated with both higher AVP and higher incidence of impaired fasting glucose in men, but not in women [56].

Individuals with lower habitual fluid intake have higher AVP levels compared to those who consume more fluids, despite similar plasma osmolality [7, 64], and increasing plain water intake can lower AVP or copeptin over hours, days, or weeks $[10,64,65]$. Compellingly, the most substantial reductions in copeptin appear to occur in those with insufficient water intake as indicated by high baseline urine osmolality, low urine volume and/or higher baseline copeptin level [65, 66]. Epidemiological evidence is inconsistent: low water intake is linked with increased risk of new-onset hyperglycemia [67], and an association between plain water intake and elevated glycated hemoglobin has been noted in men, but not women [68]. Pan et al. also found no association between plain water intake and incident T2DM in a large cohort of women [69]. In the short-term, a six-week pilot study in adults with high urine osmolality, low urine volume, and high copeptin, demonstrated that increasing water intake reduced circulating copeptin and resulted in a small but significant reduction in fasting plasma glucose, but no changes in fasting plasma insulin or glucagon [66]. However, a recent perspective paper pointed out that different manipulations to hydration have produced inconsistent results, suggesting that the relationship between water intake, hydration, AVP and metabolic response may be more complex [70].

Overall, there is convergent epidemiological evidence and a plausible mechanism for how higher circulating AVP may contribute to increased risk for metabolic disease. There is also evidence from short-term studies that in individuals with higher AVP, increasing water intake can have an AVPlowering effect [10, 64, 65]. However, longer-term studies are needed to demonstrate whether lowering AVP through increased water intake is effective in maintaining metabolic health.

\section{Lower AVP and renal water saving in chronic kidney disease (CKD)}

The rationale for use of water as a treatment in CKD is based on its ability to suppress the secretion and thus the detrimental effects of AVP on the kidneys [71, 72]. AVP increases renal hyperfiltration and renal plasma flow with its associated proteinuria, hypertension and renal scarring $[73,74]$. AVP antagonists reduce proteinuria, lower blood pressure and prevent renal injury. Water intake acts as an 


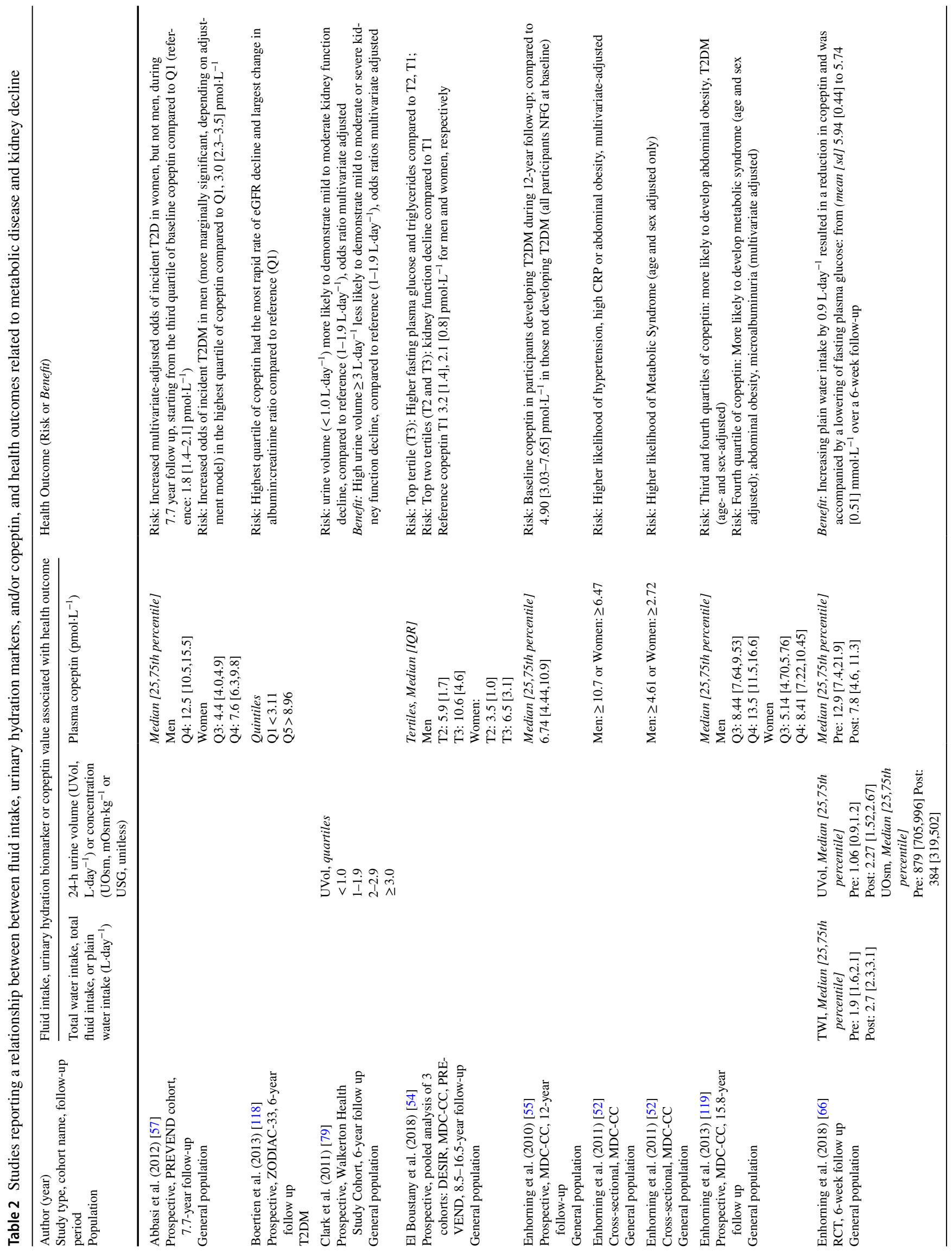




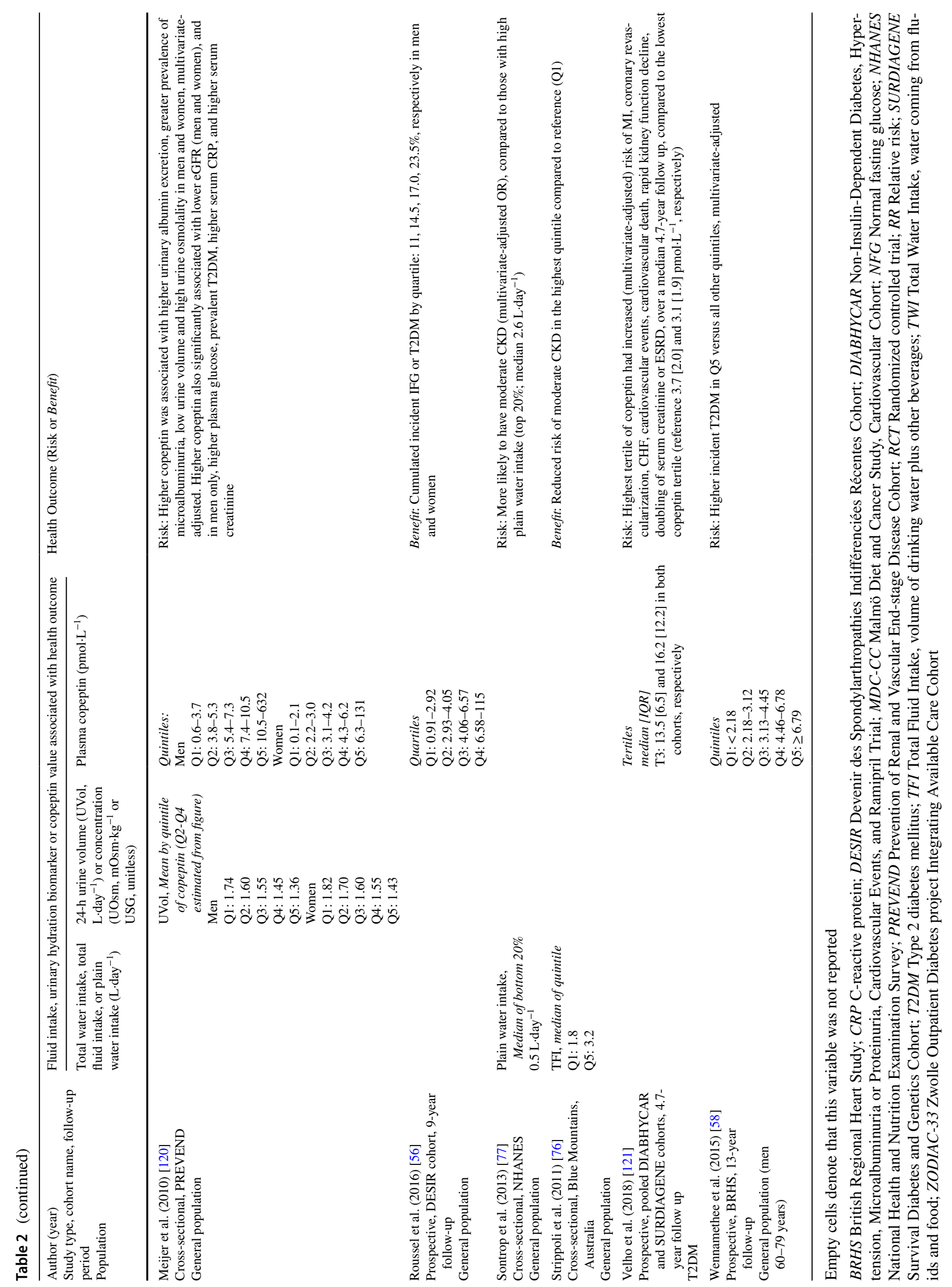


AVP antagonist, as shown by the experimental animal work of Bouby and Bankir in 1990 which demonstrated the therapeutic role of increased hydration in slowing progressive loss of kidney function [72].

Water intake and its relationship with AVP in patients with CKD is documented by various human observational studies assessing hydration as a potential therapy in CKD. However, there are inconsistencies in these studies regarding the possible benefits of increased water intake to slow and prevent CKD [75-79]. Briefly, cross-sectional studies in Australian and American cohorts have reported a kidney protective effect of higher fluid intake [76] and lower prevalence of CKD in participants reporting higher plain water intake, a beneficial effect not observed for any other type of beverage [77]. In contrast, a second prospective study analyzing longitudinal data of the same Australian cohort reported no significant association between total fluid intake and longitudinal loss of kidney function [78]. This apparent contradiction with the previous analysis may be due to the fact that plain water intake, a major driver of high fluid intake [80], was excluded from analysis. Finally, a 7-year longitudinal study of over 2000 Canadians that controlled for multiple baseline variables also demonstrated that higher urine volumes significantly predicted slower renal decline [79]. These observations are further strengthened by a longitudinal study of more than 2000 CKD patients with 15-year median follow-up demonstrating that those in the highest quartile of fluid intake had better survival outcomes than those in the lowest quartile [81].

To our knowledge there exists a single RCT on water intake in CKD prevention. In a six-week pilot study of 29 patients with stage $3 \mathrm{CKD}$, Clark et al. showed that an increased urine volume of $0.9 \mathrm{~L}$ was associated with a significant reduction in copeptin without any toxicity or measurable change in quality of life $[82,83]$. This pilot study led to the Water Intake Trial [84], a parallel-group RCT in which adults with stage 3 CKD and microalbuminuria were either coached to increase water intake by 1 to $1.5 \mathrm{~L} \mathrm{day}^{-1}$ above their usual intake (high water intake (HWI) group), or to maintain usual water intake. The primary analysis at 1-year follow-up demonstrated that a $0.6-\mathrm{L}$ increase in urine output in the HWI group versus the control group was associated with a small but significant reduction in copeptin, but not associated with a difference in albuminuria nor in estimated glomerular filtration rate (eGFR). However, this trial may have focused on the wrong population, as the majority of participants ingested approximately $2-3 \mathrm{~L}$ of fluid per day at baseline; consequently, the margin for improved hydration was small. Future RCTs should consider focusing on the role of increased hydration in low water drinkers with high copeptin levels and thus higher potential to respond to increased water intake, include more precise measures of renal function and possibly a longer follow-up.

\section{Autosomal dominant polycystic kidney disease}

Autosomal dominant polycystic kidney disease (ADPKD) is a genetic disorder characterized by development and enlargement of multiple cysts in the kidney, leading to loss of renal function, hypertension, and renal failure in $50 \%$ of patients by the age of 60 [85]. The major sites of cyst development in ADPKD are the collecting ducts and distal nephrons, where cyclic adenosine monophosphate (cAMP) stimulates both epithelial cell proliferation and fluid secretion [86]. Since AVP is a strong activator of cAMP in these loci [87, 88], the rate of progression of the disease is associated with its circulating concentration: a loss of urinary concentrating ability early in ADPKD is associated with a concomitant rise in AVP [89-93]. Further, preclinical studies demonstrate that ADPKD progression is slower in animals lacking AVP, and that in AVP knock-out animal models, desmopressin, a synthetic AVP analogue, accelerates disease progression [87, 94].

Reducing AVP action represents a recent therapeutic target for patients with ADPKD, with two possible mechanisms: (1) blocking its receptors; more specifically the V2R in the collecting ducts; or (2) decreasing circulating AVP. Administration of vaptans, a class of nonpeptide AVP receptor antagonists, in particular tolvaptan, an oral selective antagonist of the V2R, decrease cAMP in epithelial cells of the collecting ducts and distal nephron [95]. A recent RCT reported inhibition of the action of AVP by tolvaptan significantly slows the rate of disease progression [96].

The suppression of AVP by increasing water intake could also slow renal cyst growth in ADPKD [87, 88, 94, 96, 97]. Rodent models of polycystic kidney disease have shown AVP suppression by increased water intake is associated with a significant renal-protective effect [87]. However, data available in humans are limited and conflicting. A positive effect of high water intake on ADPKD was observed in one post hoc analysis [98] and two short-term interventional trials $[98,99]$ while a negative effect of high water intake was reported in a small observational cohort study [100] One large RCT is currently underway to determine the efficacy and safety of increasing water intake to prevent the progression of ADPKD over a 3-year period [101].

\section{Take home points}

- AVP, or the antidiuretic hormone, is most well-known for its central role in maintaining body water balance. However, AVP can also stimulate hepatic gluconeogenesis and glycogenolysis and can moderate glucose-regulating and corticotrophic hormones through its V1a and V1b receptors. The AVP-V2 receptor is also implicated in the pathophysiology of a particular form of kidney disease (ADPKD). 
- In epidemiological studies, higher circulating AVP, measured by its equimolar surrogate, copeptin, is associated both cross-sectionally and longitudinally with higher odds for kidney function decline, components of the metabolic syndrome, and incident T2DM.

- Short-term intervention studies suggest that in individuals with higher AVP, increasing water intake can have an AVP-lowering effect. However, it is unclear whether lowering AVP through increased water intake will reduce disease risk.

\section{Optimal hydration}

If water intake may contribute to maintaining kidney and metabolic health, what would constitute optimal hydration and how much water should one consume?

Based on the evidence above, optimal hydration should result in excretion of a generous volume of dilute urine, sufficient to avoid chronic or sustained renal water saving and excess AVP secretion. Individual needs vary; nonetheless, the available data (Tables 1,2 ) provide a starting point for practical and evidence-based recommendations.

The first recommendation is that beyond replacing daily fluid losses, optimal hydration should be viewed as allowing the excretion of a sufficient urine volume to avoid urine concentration and supersaturation. Based on the evidence for fluid intake, urine volume, and kidney stones and UTI, it would appear reasonable to maintain a volume of excreted urine of 2 to $3 \mathrm{~L}$ per day. To account for other avenues of water loss (insensible, fecal $[4,14]$ ), achieving a urine volume of 2 to $3 \mathrm{~L}$ would require consuming a fluid volume slightly higher than the AIs currently proposed by EFSA [14], and approaching the IOM AIs [4]. We suggest that daily total water intake for healthy adults in a temperate climate, performing, at most, mild to moderate physical activity should be 2.5 to $3.5 \mathrm{~L} \mathrm{day}^{-1}$. While total water intake includes water from both food and fluids, plain water is the only fluid the body needs. Plain water and other healthy beverages should make up the bulk of daily intake. A practical, evidence-based scoring tool for evaluating healthy beverage choices has been proposed by Duffey et al. [102].

The second recommendation, for healthy individuals as well as in those with metabolic dysfunction, is to drink enough to reduce excessive AVP secretion as this may be beneficial for the kidney and reduce metabolic risk. This is especially relevant for individuals who may be underhydrated [103], with low $24 \mathrm{~h}$ urine volume or high urine concentration suggestive of AVP secretion linked to insufficient water intake. While higher circulating AVP is associated with increased disease risk, to date there is insufficient data to suggest a level of copeptin which may be appropriate to target for risk reduction. However, the use of urinary biomarkers of hydration such as osmolality can provide useful information reflecting urine concentrating and diluting mechanisms and overall antidiuretic activity. Multiple authors have proposed cut-offs representing de- or hypohydration for several urinary and plasma biomarkers (Fig. 1), conversely, suggestions for optimal hydration are infrequently provided [28, 104-116]. Several years ago a cutoff of $500 \mathrm{mOsm} \mathrm{kg}{ }^{-1}$ was proposed as a reasonable target for optimal hydration, based on retrospective analyses of existing data [109] indicating that this cut-off would represent sufficient water intake to produce adequate urine

\begin{tabular}{|c|c|c|c|c|c|c|c|c|c|}
\hline $\begin{array}{l}\text { Classical hydration } \\
\text { terminology }\end{array}$ & $\begin{array}{l}\text { Updated hydration } \\
\text { terminology }\end{array}$ & $\begin{array}{c}\text { Plasma } \\
\text { osmolality } \\
\left(\mathrm{mOsm} \cdot \mathrm{kg}^{-1}\right)\end{array}$ & $\begin{array}{c}\text { Plasma } \\
\text { copeptin } \\
\text { (surrogate AVP } \\
\text { - pmol- } \mathrm{L}^{-1} \text { ) }\end{array}$ & $\begin{array}{c}\text { Urine } \\
\text { osmolality } \\
\left(\mathrm{mOsm} \cdot \mathrm{kg}^{-1}\right)\end{array}$ & $\begin{array}{c}\text { Urine specific } \\
\text { gravity } \\
\text { (unitless) }\end{array}$ & $\begin{array}{c}\text { Urine color } \\
(8 \text { point scale } \\
\text { 101) }\end{array}$ & $\begin{array}{l}\text { Urine volume } \\
\left(\mathrm{L} \cdot 24 \mathrm{~h}^{-1}\right)\end{array}$ & $\begin{array}{l}\text { Number of } \\
\text { voids }(24 \mathrm{~h})\end{array}$ & $\begin{array}{l}\text { Total body } \\
\text { water }\end{array}$ \\
\hline $\begin{array}{l}\text { Overhydration } \\
\text { Hyperhydration } \\
\text { Total body water } \\
\text { gain }\end{array}$ & $\begin{array}{c}\text { Overhydration } \\
\text { Hyperhydration } \\
\text { Homesostasis overcome }\end{array}$ & $<275^{[116]}$ & & $\underset{100}{\text { Minimum }} 50$ - & & & & & Gain \\
\hline \multirow{3}{*}{$\begin{array}{l}\text { Euhydration } \\
\text { Total body water } \\
\text { maintenance }\end{array}$} & Diuretic challenge & & & & & & & & \\
\hline & $\begin{array}{l}\text { Optimal hydration [109] } \\
\text { 'comfort zone' }\end{array}$ & $\begin{array}{c}282^{[111]} \\
280-285^{[112]} \\
275-295^{[116]} \\
292 \pm 3^{[104]}\end{array}$ & $\begin{array}{c}\text { Overall: } \leq 3 \\
\text { Men: } \leq 4 \\
\text { Women: } \leq 25\end{array}$ & $\leq 500[109]$ & $\begin{array}{l}\leq 1.010^{[28]} \\
\leq 1.012^{[108]}\end{array}$ & $<4[108,110]$ & & $\begin{array}{l}5 \pm 2[114] \\
7 \pm 2^{[115]}\end{array}$ & $\begin{array}{l}\sim 73 \% \text { fat free } \\
\text { mass }{ }^{[113]}\end{array}$ \\
\hline & $\begin{array}{l}\text { Insufficient hydration } \\
\text { Underhydration [103] } \\
\text { Water-saving } \\
\text { Antidiuretic challenge }\end{array}$ & 295-300 [116], * & $\begin{array}{c}\text { Men: } \geq 8-12 \\
\text { Women: } \geq 6-8\end{array}$ & & & & & $\begin{array}{l}3 \pm 1^{[114]} \\
5 \pm 2^{[115]}\end{array}$ & \\
\hline $\begin{array}{l}\text { Dehydration } \\
\text { Hypohydration } \\
\text { Total body water } \\
\text { loss }\end{array}$ & $\begin{array}{c}\text { Dehydration } \\
\text { Hypohydration } \\
\text { Homeostasis overcome }\end{array}$ & $\begin{array}{l}\geq 290^{[105],+} \\
>300^{[1116]} \\
301 \pm 5^{[112], \neq}\end{array}$ & & $\begin{array}{c}\geq 700[105],+ \\
830[106] \\
\geq 831[104] \\
1018 \pm 245^{[104], ~} \neq \\
\quad \text { Maximum } \\
1200-1400[111]\end{array}$ & $\begin{array}{l}\geq 1.020[105],+ \\
\geq 1.025[104] \\
1.028 \pm[104], \neq 006\end{array}$ & $\begin{array}{l}\geq 6^{[104]} \\
>6^{[107]}\end{array}$ & $\begin{array}{c}\text { Obligatory } \\
\text { minimum } \\
\text { m111] }\end{array}$ & & $\begin{array}{c}\geq 2 \% \text { body } \\
\text { water loss; } \\
\geq 1 \% \text { body } \\
\text { mass loss }{ }^{[105],+}\end{array}$ \\
\hline
\end{tabular}

Fig. 1 Terminology and associated cut-off values for common biomarkers of hydration." Defined as 'impending dehydration'. 'In the original text, these values are described as limits for euhydration (e.g., POsm <290, UOsm < 700). For clarity we have positioned these values as limits for dehydration (e.g., POsm $\geq 290$, UOsm $\geq 700$ ) in order to avoid the interpretation that these values were limits for insufficient hydration. ${ }^{+}$Decision level for $95 \%$ probability of dehydration. ${ }^{\S}$ Approximate range of plasma copeptin in bottom quartile or other reference interval (lowest risk for kidney or cardiometabolic disease)—see Table 2. "Approximate range of plasma copeptin for increased risk for kidney or cardiometabolic disease-see Table 2 
volume with respect to kidney health risk, and reduce antidiuretic effort and circulating AVP. Today, several RCTs have demonstrated that lowering $24 \mathrm{~h}$ urine osmolality to approach $500 \mathrm{mOsm} \mathrm{kg}{ }^{-1}$ or below can reduce circulating copeptin $[10,64,65]$ as well as improve metabolic markers [66] and reduce UTI incidence [42]. For clinician or home use, maintaining a urine specific gravity of less than 1.013, or a urine color of 3 or below [108] on an eight-point color scale [107], or a $24 \mathrm{~h}$ void frequency of at least 5 to 7 voids daily $[114,115]$ are suggestive of a fluid intake sufficient to achieve optimal hydration (Fig. 1). As color and void frequency are accessible without specific laboratory instruments, they may be used by the general population for daily hydration awareness.

Author contributions All authors were involved in the research design (project conception, development of overall research and review plan) and contributed substantially to the drafting and critical revision of the manuscript. ETP and FP had primary responsibility for final content; all authors had access to the references used in the preparation of this review and have read and approved the final manuscript.

Funding No funding was provided for the completion of this review.

\section{Compliance with ethical standards}

Conflict of interest ETP, JHB, AD, IG, AI, CM, IS, TV and MV are or were employed by Danone Research during the writing of this review. LEA, WCC, SAK, FL, HRL, OM, JDS, IT and FP have previously received consulting honoraria and/or research grants from Danone Research. No financial compensation was provided for the conception, drafting or critical revision of this manuscript.

Open Access This article is licensed under a Creative Commons Attribution 4.0 International License, which permits use, sharing, adaptation, distribution and reproduction in any medium or format, as long as you give appropriate credit to the original author(s) and the source, provide a link to the Creative Commons licence, and indicate if changes were made. The images or other third party material in this article are included in the article's Creative Commons licence, unless indicated otherwise in a credit line to the material. If material is not included in the article's Creative Commons licence and your intended use is not permitted by statutory regulation or exceeds the permitted use, you will need to obtain permission directly from the copyright holder. To view a copy of this licence, visit http://creativecommons.org/licenses/by/4.0/.

\section{References}

1. Perrier ET, Armstrong LE, Daudon M, Kavouras S, Lafontan M, Lang F, Peronnet F, Stookey JD, Tack I, Klein A (2014) From state to process: defining hydration. Obes Facts 7(Suppl 2):6-12. https://doi.org/10.1159/000360611

2. Johnson EC, Peronnet F, Jansen LT, Capitan-Jimenez C, Adams JD, Guelinckx I, Jimenez L, Mauromoustakos A, Kavouras SA (2017) Validation testing demonstrates efficacy of a 7-day fluid record to estimate daily water intake in adult men and women when compared with total body water turnover measurement. J Nutr 147(10):2001-2007. https://doi.org/10.3945/jn.117.25337 7
3. Raman A, Schoeller DA, Subar AF, Troiano RP, Schatzkin A, Harris T, Bauer D, Bingham SA, Everhart JE, Newman AB, Tylavsky FA (2004) Water turnover in 458 American adults 40-79 yr of age. Am J Physiol Renal Physiol 286(2):F394-F401

4. Institute of Medicine (IOM) (2004) Dietary reference intakes for water, potassium, sodium, chloride, and sulfate. National Academies Press, Washington, DC

5. Manz F, Wentz A, Sichert-Hellert W (2002) The most essential nutrient: defining the adequate intake of water. J Pediatr 141(4):587-592

6. Jequier E, Constant F (2010) Water as an essential nutrient: the physiological basis of hydration. Eur J Clin Nutr 64(2):115-123

7. Perrier E, Vergne S, Klein A, Poupin M, Rondeau P, Le Bellego L, Armstrong LE, Lang F, Stookey J, Tack I (2013) Hydration biomarkers in free-living adults with different levels of habitual fluid consumption. Br J Nutr 109(9):1678-1687. https://doi. org/10.1017/S0007114512003601

8. Johnson EC, Munoz CX, Le Bellego L, Klein A, Casa DJ, Maresh CM, Armstrong LE (2015) Markers of the hydration process during fluid volume modification in women with habitual high or low daily fluid intakes. Eur J Appl Physiol 115(5):10671074. https://doi.org/10.1007/s00421-014-3088-2

9. Perrier E, Demazieres A, Girard N, Pross N, Osbild D, Metzger D, Guelinckx I, Klein A (2013) Circadian variation and responsiveness of hydration biomarkers to changes in daily water intake. Eur J Appl Physiol 113(8):2143-2151. https://doi.org/10.1007/ s00421-013-2649-0

10. Lemetais G, Melander O, Vecchio M, Bottin JH, Enhorning S, Perrier ET (2018) Effect of increased water intake on plasma copeptin in healthy adults. Eur J Nutr 57(5):1883-1890. https:// doi.org/10.1007/s00394-017-1471-6

11. Hauff K (1991) Water: the forgotten nutrient. AGRIS 13(5):11-16

12. Wertli M, Suter PM (2006) Water-the forgotten nutrient. Praxis (Bern 1994) 95(39):1489-1495. https://doi. org/10.1024/1661-8157.95.39.1489

13. Rush EC (2013) Water: neglected, unappreciated and under researched. Eur J Clin Nutr 67:492-495

14. EFSA (2010) Scientific opinion on dietary reference values for water. EFSA Journal 8(3):1459-1506

15. Valtin H (2002) "Drink at least eight glasses of water a day." Really? Is there scientific evidence for " 8 x 8"? Am J Physiol Regul Integr Comp Physiol 283(5):R993-1004. https://doi. org/10.1152/ajpregu.00365.2002

16. Perrier E, Rondeau P, Poupin M, Le Bellego L, Armstrong LE, Lang F, Stookey J, Tack I, Vergne S, Klein A (2013) Relation between urinary hydration biomarkers and total fluid intake in healthy adults. Eur J Clin Nutr 67(9):939-943

17. Brenner B, Rector J (2008) Nephrolithiasis in Brenner and Rector's: The Kidney, 8th edn. Elsevier Saunders, Philadelphia

18. Ettinger B (1979) Recurrence of nephrolithiasis. A six-year prospective study. Am J Med 67(2):245-248

19. Hosking DH, Erickson SB, Van den Berg CJ, Wilson DM, Smith LH (1983) The stone clinic effect in patients with idiopathic calcium urolithiasis. J Urol 130(6):1115-1118

20. Sutherland JW, Parks JH, Coe FL (1985) Recurrence after a single renal stone in a community practice. Miner Electrol Metab 11(4):267-269

21. Robertson WG, Peacock M, Heyburn PJ, Marshall DH, Clark PB (1978) Risk factors in calcium stone disease of the urinary tract. Br J Urol 50(7):449-454

22. Curhan GC, Willett WC, Rimm EB, Stampfer MJ (1993) A prospective study of dietary calcium and other nutrients and the risk of symptomatic kidney stones. N Engl J Med 328(12):833-838. https://doi.org/10.1056/nejm199303253281203 
23. Borghi L, Meschi T, Amato F, Briganti A, Novarini A, Giannini A (1996) Urinary volume, water and recurrences in idiopathic calcium nephrolithiasis: a 5-year randomized prospective study. J Urol 155(3):839-843

24. Curhan GC, Taylor EN (2008) 24-h uric acid excretion and the risk of kidney stones. Kidney Int 73(4):489-496. https://doi. org/10.1038/sj.ki.5002708

25. Ratkalkar VN, Kleinman JG (2011) Mechanisms of stone formation. Clin Rev Bone Miner Metab 9(3-4):187-197. https://doi. org/10.1007/s12018-011-9104-8

26. Fink HA, Akornor JW, Garimella PS, MacDonald R, Cutting A, Rutks IR, Monga M, Wilt TJ (2009) Diet, fluid, or supplements for secondary prevention of nephrolithiasis: a systematic review and meta-analysis of randomized trials. Eur Urol 56(1):72-80. https://doi.org/10.1016/j.eururo.2009.03.031

27. Xu C, Zhang C, Wang XL, Liu TZ, Zeng XT, Li S, Duan XW (2015) Self-fluid management in prevention of kidney stones: a PRISMA-compliant systematic review and dose-response metaanalysis of observational studies. Medicine 94(27):e1042. https ://doi.org/10.1097/md.0000000000001042

28. Türk C, Knoll T, Petrik A, Sarica K, Straub CM, Seitz C (2011) Guidelines on Urolithiasis. European Association of Urology. https://uroweb.org/wp-content/uploads/20-Urolithiasis.pdf

29. Pearle MS, Goldfarb DS, Assimos DG, Curhan GC, Denu-Giocca CJ, Matlaga BR, Turk MT, White JR (2014) Medical management of kidney stones: AUA Guideline. American Urological Association (AUA) Guideline, https://www.auanet.org/docum ents/education/clinical-guidance/Medical-Management-of-Kidne y-Stones.pdf

30. McCauley LR, Dyer AJ, Stern K, Hicks T, Nguyen MM (2012) Factors influencing fluid intake behavior among kidney stone formers. J Urol 187(4):1282-1286. https://doi.org/10.1016/j. juro.2011.11.111

31. Frank M, De VA (1966) Prevention of urolithiasis. Education to adequate fluid intake in a new town situated in the Judean Desert Mountains. Arch Environ Health 13(5):625-630

32. Lotan Y, Jimenez IB, Lenoir-Wijnkoop I, Daudon M, Molinier L, Tack I, Nuijten MJ (2012) Increased water intake as a prevention strategy for recurrent urolithiasis: major impact of compliance on cost-effectiveness. J Urol 12:10

33. Lotan Y, Pearle MS (2011) Cost-effectiveness of primary prevention strategies for nephrolithiasis. J Urol 186(2):550-555. https ://doi.org/10.1016/j.juro.2011.03.133

34. Adatto K, Doebele KG, Galland L, Granowetter L (1979) Behavioral factors and urinary tract infection. JAMA 241(23):2525-2526

35. Ervin C, Komaroff AL, Pass TM (1980) Behavioral factors and urinary tract infection. JAMA 243(4):330-331

36. Pitt M (1989) Fluid intake and urinary tract infection. Nurs Times 85(1):36-38

37. Su SB, Wang JN, Lu CW (2002) Guo HR (2006) Reducing urinary tract infections among female clean room workers. J Women's Health 15(7):870-876. https://doi.org/10.1089/ jwh.2006.15.870

38. Vyas S, Varshney D, Sharma P, Juyal R, Nautiyal V, Shrotriya $\mathrm{V}$ (2015) An overview of the predictors of symptomatic urinary tract infection among nursing students. Ann Med Health Sci Res 5(1):54-58. https://doi.org/10.4103/2141-9248.149790

39. Remis RS, Gurwith MJ, Gurwith D, Hargrett-Bean NT, Layde PM (1987) Risk factors for urinary tract infection. Am J Epidemiol 126(4):685-694

40. Robinson SB, Rosher RB (2002) Can a beverage cart help improve hydration? Geriatr Nurs 23(4):208-211
41. Eckford SD, Keane DP, Lamond E, Jackson SR, Abrams P (1995) Hydration monitoring in the prevention of recurrent idiopathic urinary tract infections in premenopausal women. Br J Urol 76:90-93

42. Hooton TM, Vecchio M, Iroz A, Tack I, Dornic Q, Seksek I, Lotan Y (2018) Effect of increased daily water intake in premenopausal women with recurrent urinary tract infections: a randomized clinical trial. JAMA Intern Med 178(11):1509-1515. https://doi.org/10.1001/jamainternmed.2018.4204

43. Lean K, Nawaz RF, Jawad S, Vincent C (2019) Reducing urinary tract infections in care homes by improving hydration. BMJ Open Qual 8(3):e000563-e000563. https://doi.org/10.1136/bmjoq $-2018-000563$

44. Bankir L (2001) Antidiuretic action of vasopressin: quantitative aspects and interaction between V1a and V2 receptor-mediated effects. Cardiovasc Res 51(3):372-390

45. Morgenthaler NG, Struck J, Alonso C, Bergmann A (2006) Assay for the measurement of copeptin, a stable peptide derived from the precursor of vasopressin. Clin Chem 52(1):112-119

46. Mavani GP, DeVita MV, Michelis MF (2015) A review of the nonpressor and nonantidiuretic actions of the hormone vasopressin. Front Med 2:19. https://doi.org/10.3389/fmed.2015.00019

47. Whitton PD, Rodrigues LM, Hems DA (1978) Stimulation by vasopressin, angiotensin and oxytocin of gluconeogenesis in hepatocyte suspensions. Biochem J 176(3):893-898

48. Keppens S, de Wulf H (1979) The nature of the hepatic receptors involved in vasopressin-induced glycogenolysis. Biochem Biophys Acta 588(1):63-69

49. Abu-Basha EA, Yibchok-Anun S, Hsu WH (2002) Glucose dependency of arginine vasopressin-induced insulin and glucagon release from the perfused rat pancreas. Metabolism 51(9):1184-1190

50. Rizza RA, Mandarino LJ, Gerich JE (1982) Cortisol-induced insulin resistance in man: impaired suppression of glucose production and stimulation of glucose utilization due to a postreceptor detect of insulin action. J Clin Endocrinol Metab 54(1):131138. https://doi.org/10.1210/jcem-54-1-131

51. Tanoue A, Ito S, Honda K, Oshikawa S, Kitagawa Y, Koshimizu TA, Mori T, Tsujimoto G (2004) The vasopressin V1b receptor critically regulates hypothalamic-pituitary-adrenal axis activity under both stress and resting conditions. J Clin Invest 113(2):302-309. https://doi.org/10.1172/jci19656

52. Enhorning S, Struck J, Wirfalt E, Hedblad B, Morgenthaler NG, Melander O (2011) Plasma copeptin, a unifying factor behind the metabolic syndrome. J Clin Endocrinol Metab 96(7):1065-1072. https://doi.org/10.1210/jc.2010-2981

53. Saleem U, Khaleghi M, Morgenthaler NG, Bergmann A, Struck J, Mosley TH Jr, Kullo IJ (2009) Plasma carboxy-terminal provasopressin (copeptin): a novel marker of insulin resistance and metabolic syndrome. J Clin Endocrinol Metab 94(7):2558-2564. https://doi.org/10.1210/jc.2008-2278

54. El Boustany R, Tasevska I, Meijer E, Kieneker LM, Enhorning S, Lefevre G, Mohammedi K, Marre M, Fumeron F, Balkau B, Bouby N, Bankir L, Bakker SJ, Roussel R, Melander O, Gansevoort RT, Velho G (2018) Plasma copeptin and chronic kidney disease risk in 3 European cohorts from the general population. JCI Insight. https://doi.org/10.1172/jci.insight.121479

55. Enhorning S, Wang TJ, Nilsson PM, Almgren P, Hedblad B, Berglund G, Struck J, Morgenthaler NG, Bergmann A, Lindholm E, Groop L, Lyssenko V, Orho-Melander M, Newton-Cheh C, Melander O (2010) Plasma copeptin and the risk of diabetes mellitus. Circulation 121(19):2102-2108. https://doi.org/10.1161/ CIRCULATIONAHA.109.909663 
56. Roussel R, El Boustany R, Bouby N, Potier L, Fumeron F, Mohammedi K, Balkau B, Tichet J, Bankir L, Marre M, Velho G (2016) Plasma copeptin, AVP gene variants, and incidence of type 2 diabetes in a cohort from the community. J Clin Endocrinol Metab 101(6):2432-2439. https://doi.org/10.1210/ jc.2016-1113

57. Abbasi A, Corpeleijn E, Meijer E, Postmus D, Gansevoort RT, Gans RO, Struck J, Hillege HL, Stolk RP, Navis G, Bakker SJ (2012) Sex differences in the association between plasma copeptin and incident type 2 diabetes: the Prevention of Renal and Vascular Endstage Disease (PREVEND) study. Diabetologia 55(7):1963-1970. https://doi.org/10.1007/s00125-012-2545-X

58. Wannamethee SG, Welsh P, Papacosta O, Lennon L, Whincup PH, Sattar N (2015) Copeptin, insulin resistance, and risk of incident diabetes in older men. J Clin Endocrinol Metab 100(9):3332-3339. https://doi.org/10.1210/jc.2015-2362

59. Velho G, Bouby N, Hadjadj S, Matallah N, Mohammedi K, Fumeron F, Potier L, Bellili-Munoz N, Taveau C, Alhenc-Gelas F, Bankir L, Marre M, Roussel R (2013) Plasma copeptin and renal outcomes in patients with type 2 diabetes and albuminuria. Diabetes Care 36(11):3639-3645. https://doi.org/10.2337/dc13-0683

60. Riphagen IJ, Boertien WE, Alkhalaf A, Kleefstra N, Gansevoort RT, Groenier KH, van Hateren KJ, Struck J, Navis G, Bilo HJ, Bakker SJ (2013) Copeptin, a surrogate marker for arginine vasopressin, is associated with cardiovascular and all-cause mortality in patients with type 2 diabetes (ZODIAC-31). Diabetes Care 36(10):3201-3207. https://doi.org/10.2337/dc12-2165

61. Enhorning S, Hedblad B, Nilsson PM, Engstrom G, Melander $\mathrm{O}(2015)$ Copeptin is an independent predictor of diabetic heart disease and death. Am Heart J 169(4):549-556. https://doi. org/10.1016/j.ahj.2014.11.020

62. Taveau C, Chollet C, Waeckel L, Desposito D, Bichet DG, Arthus MF, Magnan C, Philippe E, Paradis V, Foufelle F, Hainault I, Enhorning S, Velho G, Roussel R, Bankir L, Melander O, Bouby N (2015) Vasopressin and hydration play a major role in the development of glucose intolerance and hepatic steatosis in obese rats. Diabetologia 58(5):1081-1090. https://doi.org/10.1007/ s00125-015-3496-9

63. Taveau C, Chollet C, Bichet DG, Velho G, Guillon G, Corbani M, Roussel R, Bankir L, Melander O, Bouby N (2017) Acute and chronic hyperglycemic effects of vasopressin in normal rats: involvement of V1A receptors. Am J Physiol Endocrinol Metab 312(3):E127-E135. https://doi.org/10.1152/ajpendo.00269.2016

64. Johnson EC, Munoz CX, Jimenez L, Le Bellego L, Kupchak BR, Kraemer WJ, Casa DJ, Maresh CM, Armstrong LE (2016) Hormonal and thirst modulated maintenance of fluid balance in young women with different levels of habitual fluid consumption. Nutrients. https://doi.org/10.3390/nu8050302

65. Enhorning S, Tasevska I, Roussel R, Bouby N, Persson M, Burri P, Bankir L, Melander O (2017) Effects of hydration on plasma copeptin, glycemia and gluco-regulatory hormones: a water intervention in humans. Eur J Nutr 58(1):315-324. https://doi. org/10.1007/s00394-017-1595-8

66. Enhorning S, Brunkwall L, Tasevska I, Ericson U, Tholin JP, Persson M, Lemetais G, Vanhaecke T, Dolci A, Perrier ET, Melander O (2018) Water supplementation reduces copeptin and plasma glucose in adults with high copeptin: the $\mathrm{H} 2 \mathrm{O}$ metabolism pilot study. J Clin Endocrinol Metab 104(6):1917-1925. https://doi.org/10.1210/jc.2018-02195

67. Roussel R, Fezeu L, Bouby N, Balkau B, Lantieri O, AlhencGelas F, Marre M, Bankir L (2011) Low water intake and risk for new-onset hyperglycemia. Diabetes Care 34(12):2551-2554. https://doi.org/10.2337/dc11-0652

68. Carroll HA, Betts JA, Johnson L (2016) An investigation into the relationship between plain water intake and glycated $\mathrm{Hb}$
(HbA1c): a sex-stratified, cross-sectional analysis of the UK National Diet and Nutrition Survey (2008-2012). Br J Nutr 116(10):1770-1780. https://doi.org/10.1017/s00071145160036 88

69. Pan A, Malik VS, Schulze MB, Manson JE, Willett WC, Hu FB (2012) Plain-water intake and risk of type 2 diabetes in young and middle-aged women. Am J Clin Nutr 95(6):1454-1460. https ://doi.org/10.3945/ajen.111.032698

70. Carroll HA, James LJ (2019) Hydration, arginine vasopressin, and glucoregulatory health in humans: a critical perspective. Nutrients. https://doi.org/10.3390/nu11061201

71. Bardoux P, Bichet DG, Martin H, Gallois Y, Marre M, Arthus MF, Lonergan M, Ruel N, Bouby N, Bankir L (2003) Vasopressin increases urinary albumin excretion in rats and humans: involvement of $\mathrm{V} 2$ receptors and the renin-angiotensin system. Nephrol Dial Transplant 18(3):497-506

72. Bouby N, Bachmann S, Bichet D, Bankir L (1990) Effect of water intake on the progression of chronic renal failure in the $5 / 6$ nephrectomized rat. Am J Physiol 258(4 Pt 2):F973-979. https:// doi.org/10.1152/ajprenal.1990.258.4.F973

73. Bardoux P, Martin H, Ahloulay M, Schmitt F, Bouby N, TrinhTrang-Tan MM, Bankir L (1999) Vasopressin contributes to hyperfiltration, albuminuria, and renal hypertrophy in diabetes mellitus: study in vasopressin-deficient Brattleboro rats. Proc Natl Acad Sci U S A 96(18):10397-10402

74. Bolignano D, Zoccali C (2010) Vasopressin beyond water: implications for renal diseases. Curr Opin Nephrol Hypertens 19(5):499-504. https://doi.org/10.1097/MNH.0b013e32833d35c $\mathrm{f}$

75. Hebert LA, Greene T, Levey A, Falkenhain ME, Klahr S (2003) High urine volume and low urine osmolality are risk factors for faster progression of renal disease. Am J Kidney Dis 41(5):962-971

76. Strippoli GF, Craig JC, Rochtchina E, Flood VM, Wang JJ, Mitchell P (2011) Fluid and nutrient intake and risk of chronic kidney disease. Nephrology 16(3):326-334

77. Sontrop JM, Dixon SN, Garg AX, Buendia-Jimenez I, Dohein O, Huang SH, Clark WF (2013) Association between water intake, chronic kidney disease, and cardiovascular disease: a cross-sectional analysis of NHANES data. Am J Nephrol 37(5):434-442

78. Palmer SC, Wong G, Iff S, Yang J, Jayaswal V, Craig JC, Rochtchina E, Mitchell P, Wang JJ, Strippoli GF (2014) Fluid intake and all-cause mortality, cardiovascular mortality and kidney function: a population-based longitudinal cohort study. Nephrol Dial Transpl 29(7):1377-1384. https://doi.org/10.1093/ ndt/gft507

79. Clark WF, Sontrop JM, Macnab JJ, Suri RS, Moist L, Salvadori M, Garg AX (2011) Urine volume and change in estimated GFR in a community-based cohort study. Clin J Am Soc Nephrol 6(11):2634-2641

80. Perrier E, Klein A, Guelinckx I (2014) Water from fluids is the main driver of total water intake in healthy French adults. In: Paper presented at the 38th National Nutrient Databank Conference. https://www.nutrientdataconf.org/PastConf/NDBC38/ NNDC38_PosterAbstracts.pdf

81. Wu LW, Chen WL, Liaw FY, Sun YS, Yang HF, Wang CC, Lin CM, Tsao YT (2016) Association between fluid intake and kidney function, and survival outcomes analysis: a nationwide population-based study. BMJ Open 6(5):e010708. https://doi. org/10.1136/bmjopen-2015-010708

82. Clark WF, Sontrop JM, Huang SH, Gallo K, Moist L, House AA, Weir MA, Garg AX (2013) The chronic kidney disease Water Intake Trial (WIT): results from the pilot randomised controlled 
trial. BMJ Open 3(12):e003666. https://doi.org/10.1136/bmjop en-2013-003666

83. Sontrop JM, Huang SH, Garg AX, Moist L, House AA, Gallo K, Clark WF (2015) Effect of increased water intake on plasma copeptin in patients with chronic kidney disease: results from a pilot randomised controlled trial. BMJ Open 5(11):e008634. https://doi.org/10.1136/bmjopen-2015-008634

84. Clark WF, Sontrop JM, Huang SH, Gallo K, Moist L, House AA, Cuerden MS, Weir MA, Bagga A, Brimble S, Burke A, Muirhead N, Pandeya S, Garg AX (2018) Effect of coaching to increase water intake on kidney function decline in adults with chronic kidney disease: The CKD WIT randomized clinical trial. JAMA 319(18):1870-1879. https://doi.org/10.1001/jama.2018.4930

85. Chebib FT, Torres VE (2016) Autosomal dominant polycystic kidney disease: core curriculum 2016. Am J Kidney Dis 67(5):792-810. https://doi.org/10.1053/j.ajkd.2015.07.037

86. Grantham JJ (2003) Lillian Jean Kaplan International Prize for advancement in the understanding of polycystic kidney disease. Understanding polycystic kidney disease: a systems biology approach. Kidney Int 64(4):1157-1162

87. Wang X, Wu Y, Ward C, Harris P, Torres V (2008) Vasopressin directly regulates cyst growth in polycystic kidney disease. J Am Soc Nephrol 19:102-108

88. Gattone V, Wang X, Harris P, Torres V (2003) Inhibition of renal cystic disease development and progression by a vasopressin V2 receptor antagonist. Nat Med 9:1323-1326

89. Kaariainen H, Koskimies O, Norio R (1988) Dominant and recessive polycystic kidney disease in children: evaluation of clinical features and laboratory data. Pediatric Nephrol 2:296-302

90. Phillips J, Hopwood D, Loxley R, Ghatora K, Coombes J, Tan Y, Harrison J, McKitrick D, Holobotvskyy V, Arnolda L, Rangan G (2007) Temporal relationship between renal cyst development, hypertension and cardiac hypertrophy in a new rat model of autosomal recessive polycystic kidney disease. Kidney Blood Press Res 30:129-144

91. van Gastel M, Torres V (2017) Polycystic kidney disease and the vasopressin pathway. Ann Nutr Metab 70(s1):43-50

92. Zittema D, Boertien W, van Beek A, Dullaart R, Franssen C, de Jong P, Meijer E, Gansevoort R (2012) Vasopressin, copeptin, and renal concentrating capacity in patients with autosomal dominant polycystic kidney disease without renal impairment. Clin J Am Soc Nephrol 7:906-913

93. Ho T, Godefroid N, Gruzon D, Haymann J, Marechal C, Wang X, Serra A, Pirson Y, Devuyst O (2012) Autosomal dominant polycystic kidney disease is associated with central and nephrogenic defects in osmoregulation. Kidney Int 82:1121-1129

94. Torres BL, Grantham JJ (2009) A case for water in the treatment of polycystic kidney disease. Clin J Am Soc Nephrol 2009:1140-1150

95. Torres VE, Harris PC (2014) Strategies targeting cAMP signaling in the treatment of polycystic kidney disease. J Am Soc Nephrol 25(1):18-32. https://doi.org/10.1681/ASN.2013040398

96. Torres VECA, Devuyst O et al (2012) Tolvaptan in patients with autosomal dominant polycystic kidney disease. New Engl J Med 367:2407-2418

97. Wang CJ, Grantham JJ, Wetmore JB (2013) The medicinal use of water in renal disease. Kidney Int 84(1):45-53

98. Barash I, Ponda MP, Goldfarb DS, Skolnik EY (2010) A pilot clinical study to evaluate changes in urine osmolality and urine cAMP in response to acute and chronic water loading in autosomal dominant polycystic kidney disease. Clin J Am Soc Nephrol 5(4):693-697. https://doi.org/10.2215/cjn.04180609
99. Wang CJ, Creed C, Winklhofer FT, Grantham JJ (2011) Water prescription in autosomal dominant polycystic kidney disease: a pilot study. Clin J Am Soc Nephrol 6(1):192-197. https://doi. org/10.2215/cjn.03950510

100. Higashihara E, Nutahara K, Tanbo M, Hara H, Miyazaki I, Kobayashi K, Nitatori T (2014) Does increased water intake prevent disease progression in autosomal dominant polycystic kidney disease? Nephrol Dial Transpl 29(9):1710-1719. https://doi. org/10.1093/ndt/gfu093

101. Wong ATY, Mannix C, Grantham JJ, Allman-Farinelli M, Badve SV, Boudville N, Byth K, Chan J, Coulshed S, Edwards ME, Erickson BJ, Fernando M, Foster S, Haloob I, Harris DCH, Hawley CM, Hill J, Howard K, Howell M, Jiang SH, Johnson DW, Kline TL, Kumar K, Lee VW, Lonergan M, Mai J, McCloud P, Peduto A, Rangan A, Roger SD, Sud K, Torres V, Vliayuri E, Rangan GK (2018) Randomised controlled trial to determine the efficacy and safety of prescribed water intake to prevent kidney failure due to autosomal dominant polycystic kidney disease (PREVENT-ADPKD). BMJ Open 8(1):e018794. https://doi. org/10.1136/bmjopen-2017-018794

102. Duffey KJ, Davy BM (2015) The healthy beverage index is associated with reduced cardiometabolic risk in US adults: a preliminary analysis. J Acad Nutr Diet 115(10):1682-1689.e1682. https ://doi.org/10.1016/j.jand.2015.05.005

103. Kavouras SA (2019) Hydration, dehydration, underhydration, optimal hydration: are we barking up the wrong tree? Eur J Nutr 58:471-473. https://doi.org/10.1007/s00394-018-01889-z

104. Cheuvront SN, Ely BR, Kenefick RW, Sawka MN (2010) Biological variation and diagnostic accuracy of dehydration assessment markers. Am J Clin Nutr 92(3):565-573

105. Sawka MN, Burke LM, Eichner ER, Maughan RJ, Montain SJ, Stachenfeld NS (2007) American college of sports medicine position stand exercise and fluid replacement. Med Sci Sports Exerc 39(2):377-390

106. Manz F, Wentz A (2003) 24-h hydration status: parameters, epidemiology and recommendations. Eur J Clin Nutr 57(Suppl 2):10-18

107. Armstrong LE, Maresh CM, Castellani JW, Bergeron MF, Kenefick RW, LaGasse KE, Riebe D (1994) Urinary indices of hydration status. Int J Sport Nutr 4(3):265-279

108. Perrier ET, Bottin JH, Vecchio M, Lemetais G (2017) Criterion values for urine-specific gravity and urine color representing adequate water intake in healthy adults. Eur J Clin Nutr 71(4):561-563. https://doi.org/10.1038/ejcn.2016.269

109. Perrier ET, Buendia-Jimenez I, Vecchio M, Armstrong LE, Tack I, Klein A (2015) Twenty-four-hour urine osmolality as a physiological index of adequate water intake. Dis Markers 2015:231063. https://doi.org/10.1155/2015/231063

110. McKenzie AL, Munoz CX, Ellis LA, Perrier ET, Guelinckx I, Klein A, Kavouras SA, Armstrong LE (2017) Urine color as an indicator of urine concentration in pregnant and lactating women. Eur J Nutr 56(1):355-362. https://doi.org/10.1007/s0039 4-015-1085-9

111. Guyton AC, Hall JE (2006) Regulation of extracellular fluid osmolarity and sodium concentration. In: Textbook of medical physiology. 11 edn, Elsevier: Philadelphia

112. Brenner BM, Rector FC (2008) Brenner \& Rector's The kidney, 8th edn. Saunders, United States

113. Wang Z, Deurenberg P, Wang W, Pietrobelli A, Baumgartner RN, Heymsfield SB (1999) Hydration of fat-free body mass: review and critique of a classic body-composition constant. Am J Clin Nutr 69(5):833-841 
114. Burchfield JM, Ganio MS, Kavouras SA, Adams JD, Gonzalez MA, Ridings CB, Moyen NE, Tucker MA (2015) 24-h Void number as an indicator of hydration status. Eur J Clin Nutr 69(5):638-641. https://doi.org/10.1038/ejen.2014.278

115. Tucker MA, Gonzalez MA, Adams JD, Burchfield JM, Moyen NE, Robinson FB, Schreiber BA, Ganio MS (2016) Reliability of 24-h void frequency as an index of hydration status when euhydrated and hypohydrated. Eur J Clin Nutr 70(8):908-911. https://doi.org/10.1038/ejen.2015.233

116. Thomas DR, Cote TR, Lawhorne L, Levenson SA, Rubenstein LZ, Smith DA, Stefanacci RG, Tangalos EG, Morley JE (2008) Understanding clinical dehydration and its treatment. J Am Med Dir Assoc 9(5):292-301. https://doi.org/10.1016/j.jamda .2008.03.006

117. Curhan GC, Willett WC, Knight EL, Stampfer MJ (2004) Dietary factors and the risk of incident kidney stones in younger women: nurses' health study II. Arch Intern Med 164(8):885-891

118. Boertien WE, Riphagen IJ, Drion I, Alkhalaf A, Bakker SJ, Groenier KH, Struck J, de Jong PE, Bilo HJ, Kleefstra N, Gansevoort RT (2013) Copeptin, a surrogate marker for arginine vasopressin, is associated with declining glomerular filtration in patients with diabetes mellitus (ZODIAC-33). Diabetologia 56(8):1680-1688. https://doi.org/10.1007/s00125-013-2922-0

119. Enhorning S, Bankir L, Bouby N, Struck J, Hedblad B, Persson M, Morgenthaler NG, Nilsson PM, Melander O (2013) Copeptin, a marker of vasopressin, in abdominal obesity, diabetes and microalbuminuria: the prospective malmo diet and cancer study cardiovascular cohort. Int J Obes 37(4):598-603. https://doi. org/10.1038/ijo.2012.88

120. Meijer E, Bakker SJ, Halbesma N, de Jong PE, Struck J, Gansevoort RT (2010) Copeptin, a surrogate marker of vasopressin, is associated with microalbuminuria in a large population cohort. Kidney Int 77(1):29-36. https://doi.org/10.1038/ki.2009.397

121. Velho G, Ragot S, El Boustany R, Saulnier PJ, Fraty M, Mohammedi K, Fumeron F, Potier L, Marre M, Hadjadj S, Roussel R (2018) Plasma copeptin, kidney disease, and risk for cardiovascular morbidity and mortality in two cohorts of type 2 diabetes. Cardiovascular diabetology 17(1):110. https://doi.org/10.1186/ s12933-018-0753-5 